\title{
Teacher's Attitudes as Knowledge Predictors
}

Oscar E. Quirós*12 ${ }^{2}$, Gloriana Chaverri ${ }^{12}$, Paula Iturralde-Polit ${ }^{3}$, Karen Miranda ${ }^{1}$, Santiago SandiUreña $^{14}$.

${ }^{1}$ Fundación Universidad Golfito, Alamedas, Golfito, 60701

${ }^{2}$ Universidad de Costa Rica, Golfito, 60701

${ }^{3}$ SEP, Universidad de Costa Rica, San Pedro, 11501

${ }^{4}$ School of Chemistry, Universidad de Costa Rica, San Pedro, 11501

*Correspondence: oscar.quirosruiz@ucr.ac.cr

\begin{abstract}
:
Attitudes and behaviours towards the natural environment have been extensively studied in certain cultural settings during the last 40 years. In education, the teacher's ability to grasp the fundamentals of an academic subject may define his or her own attitudes towards that discipline; certainly the reverse is also valid. The correlations between affective and cognitive domains appear to play a significant role in teaching-learning dynamics. In this study we seek to assess whether the affective posture towards school sciences of a cohort of teachers in rural communities shows an association with their cognitive competence in the disciplines. The results of this study provide evidence that there is a statistically significant correlation between the cognitive and affective domains for in-service teachers. The affective domain, therefore, could serve as a predictor for cognitive competency and self-efficacy expectancies with respect to both content and career fulfilment.
\end{abstract}

Keywords: Career choice predictors, Affective and Cognitive Domains, Science teacher training, International teaching.

\section{Introduction:}

Attitudes and behaviours towards the natural environment have been extensively studied in certain cultural settings during the last 40 years (Thompson \& Mintzes, 2002). A reasonable assumption in Kraus 's (1995) view, is that 'attitudes, in some way, guide, influence, direct, shape or predict behavior'. Thompson's and Mintzes' study about attitudes towards sharks and 
how it relates to knowledge about them serves as a launching point for our research about the relationship between attitudes (affective domain) and knowledge (cognitive domain) for inservice science teachers. It has been discussed that emotional investment in the educational process generates positive outcomes (Walls, Nardi, von Minden, \& Hoffman, 2002; Shoffner, 2009; Bathgate \& Schunn, 2017). The emotional environment that teachers provide, whether positive or negative, greatly influences the quality of education in the classroom. Students, therefore, see their learning experiences improved or deteriorated accordingly (Knuver \& Brandsma, 1993)(Grauer, 2014). The plausibility of this effect validates the significance of the affective domain in the teaching-learning continuum. Given the bidirectional nature of the educational process, teacher emotional involvement impacts not only student attitude towards learning but also the teacher's experience as an educator. A teacher's emotional involvement in this bidirectional effort impacts not only the students' entire attitude towards learning but also the teacher's experience as an educator (Bathgate \& Schunn, 2017).

The attitude towards science impacts the teacher's ability to master the discipline, conveys a positive attitude towards science, and therefore his or her becoming an effective teacher (Walls et al., 2002; Grauer, 2014). The correlations between affective and cognitive domains appear to play a significant role in teaching-learning dynamics (Baker, 2010). Thus, the affective domain might serve as a predictor for the cognitive domain mastery. In this study we seek to assess whether the affective posture towards school sciences of a cohort of teachers in rural communities shows an association with their cognitive competence in the disciplines. In addition, we would like to know if years of service, type of university where the teacher graduated, and academic degree level have any influence in the cognitive/affective association.

\section{Methodology:}

To accomplish our goal, we developed a multi-layered instrument to assess teacher mastery of physics, chemistry and biology, as well as the affective attitude towards science and science education. The disciplinary content items were based on the Costa Rican national standards set by the Ministry of Public Education for grades $7^{\text {th }}$. through $11^{\text {th }}$. (Sevilla Solano, et al, 2012; Villalobos \& Jiménez, 2012; Valverde, Alfaro, Navas, Castillo, \& Acón, 2012; Díaz, Umaña, Quesada, Benavides, \& Sandí, 2012). The affective items were designed using Bloom's modified taxonomy (Anderson et al., 2001; Anderson, 2005; Krathwohl \& Anderson, 2010) 
grouped in two sets: one to scale teacher perceptions on how much they like subjects such as mathematics and sciences, and the other to gauge teachers' perceptions on the level of difficulty or easiness mathematics and sciences represent for them.

The research project was approved by the Fundación Universidad Golfito Record 21, on the 8 of October, 2014. Data were collected from August to October 2016 based on a threesection survey instrument. One section with 12 questions was aimed at collecting demographic information such as years of professional experience, name of institution that conferred highest degree, and highest degree obtained. The second section addressed the affective domain. It was divided into two subsections, one made out of 55 items, the other with 24 items both on a sevenstep Likert scale. The first subsection was intended to collect data on the overall liking or dislike each teacher had for the three sciences. The second subsection collected data on teachers' perceived level of difficulty/easiness associated with biology, physics and chemistry. The third section of the survey addressed the cognitive domain. The items were distributed to include the following cognitive dimensions: Remember, Understand, Apply, Analyse and Evaluate. The chemistry diagnostic test focused on Units I, II and III of the Ministry of Education (MEP) Chemistry Program. Units IV and V are covered in 11th grade (senior year in the local school system) and represent knowledge and skills that are more specific. It included all seven units of physics for $10^{\text {th }}$ grade and the three units corresponding to $7^{\text {th }}$ grade. The biology diagnostic test was based on the six units corresponding to $10^{\text {th }}$ and $11^{\text {th }}$ grades. The instrument was administered to 109 out of 112 active teachers from 51 secondary schools in the South-western region of Costa Rica. It included a range of teachers spanning from those working as the sole science faculty in small rural schools to larger urban institutions with more than 14 science teachers and 800 students. Some of the schools were inside Indigenous Territories (autonomous lands inhabited by native ethnic groups) with a total student population of no more than 50 pupils. All teachers were selected and hired by the centralized processing system at the Ministry of Education in San José, with the exception of those in the indigenous territories who were selected by each territory's council.

The data were collected during scheduled visits to each school. Teachers took between 45 minutes and 2.5 hours to complete the survey. They were given the option to take one or more of the cognitive tests, depending on how competent they felt in the three science subjects. Since our 
core question is about the relationship between the affective and the cognitive domain, the cognitive test option allows for the teacher to be assessed in the area he or she feels more competent. These preferred cognitive tests provide the best score possible from each individual (Dreyfuss \& Dreyfus, 1980). The cognitive section was scored on a 0 to 10 scale. Institution of highest degree was arranged into private and public university groups in order to have an adequate sample size per category. The affective data were averaged by discipline per individual, for each of the two sets of responses. The first set (A1) gauges the teacher liking or dislike towards the three sciences. The second set (A2) gauges the level of difficulty they feel towards the three subject matters.

The data were analysed using partial least square regression analysis (PLS), in InfoStat (Di Rienzo, Casanoves, Balzarini, Tablada, \& Robledo, 2017). Our primary hypothesis was that the affective domain is associated with the cognitive domain. The analysis includes demographic data on level of academic degree, type of institution (private or public), and number of years of service as variables that may also explain the results of the affective and cognitive tests. The cognitive data include the score per teacher. The affective data consist of Set 1 (A1) for like/dislike, whereupon a higher score indicates a greater positive attitude towards that subject, and Set 2 (A2) for difficulty/easiness values, whereupon higher scores indicate that a specific subject is perceived as more difficult.

\section{Results:}

Out of the 109 informants, 57 were females, and 52 were males. Ten teachers did not hold any university degree at the time of the study (but were working towards a bachelor's degree), 45 had a bachelor's degree (B.A.), 49 had a "licentiate" degree (Lic.) and 5 had a Master's degree (M.A.). Seventy-one teachers received their last degree from 14 different private universities and 38 from three public universities. The work experience of informants ranges from three months to thirty-two years, with an average of 11.5 years. Teachers without a bachelor's degree have an average of 7.9 years of service, while those with a master's degree have 20.5 years of service.

Our results show that teachers with higher scores in the cognitive tests for biology, physics and chemistry also typically have a more positive assessment of affective data in A1 (Figure 1), which measures whether they like that subject or not. For example, results of the PLS 
indicate that performing better in cognitive tests in physics (as seen by larger values in the $x$ axis, Figure 1) is associated with performing better in A1. Similar results are observed for chemistry and biology. The pattern of correlation between cognitive results and affective data A2 is not consistent among sciences. In biology, higher scores on cognitive tests are associated with higher values of A2, indicating that those that do better also find this topic more difficult, yet for chemistry higher grades in the cognitive test are associated with lower values of A2 (i.e., teachers that do better in cognitive tests find this topic easier), and there is no correlation between results of A2 and cognitive tests in physics (Figure 1).

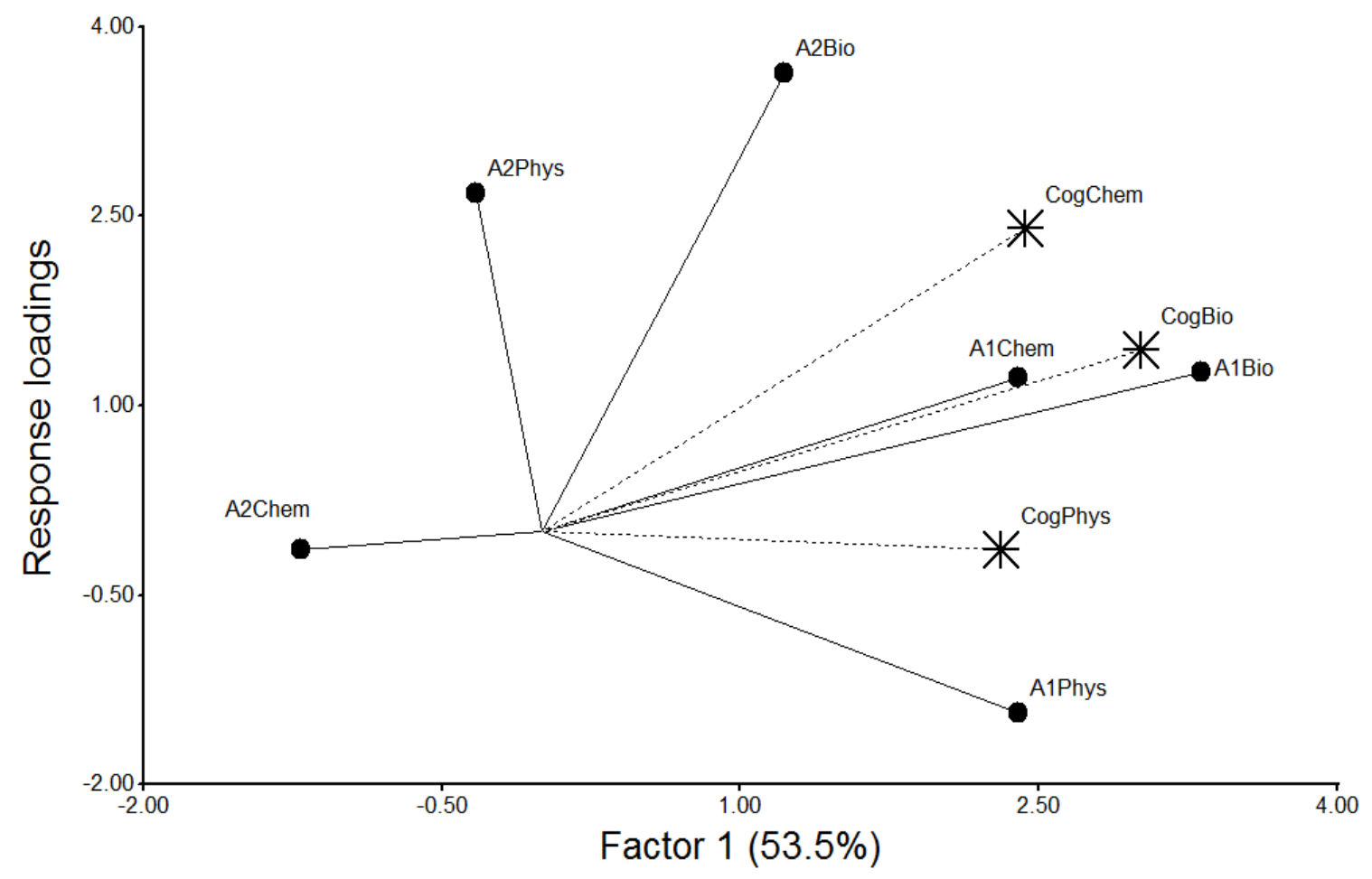

Figure 1. Biplot showing the correlation between cognitive (Cog) tests in chemistry (Chem), physics (Phys) and biology (Bio), and affective dimensions A1 and A2 for all three sciences. Results are based on the Partial Least Squares analysis, and higher values for each variable are represented by larger values of Factor 1. A correlation between variables can be either positive if lines run within ca. $45^{\circ}$ of each other, negative if they run in opposite directions, or alternatively there can be no correlation if the angle between the two lines representing the variables is ca. $90^{\circ}$.

When analysing cognitive results based on demographic data, we found that more years of teaching experience were associated with higher scores in the cognitive tests for physics, and to a lesser extent to chemistry and finally biology (Figure 2). A higher academic degree is 
associated with higher scores for chemistry and biology, but not in physics. Finally, the type of university (i.e., lower values represent public universities, and higher values represent private ones) is negatively correlated with results in cognitive tests primarily for physics, but also with chemistry and biology, albeit to a lesser extent (Figure 2). This means that cognitive tests for teachers in public universities were generally higher than those of teachers that attended private universities, and the correlation seems to be stronger for physics.

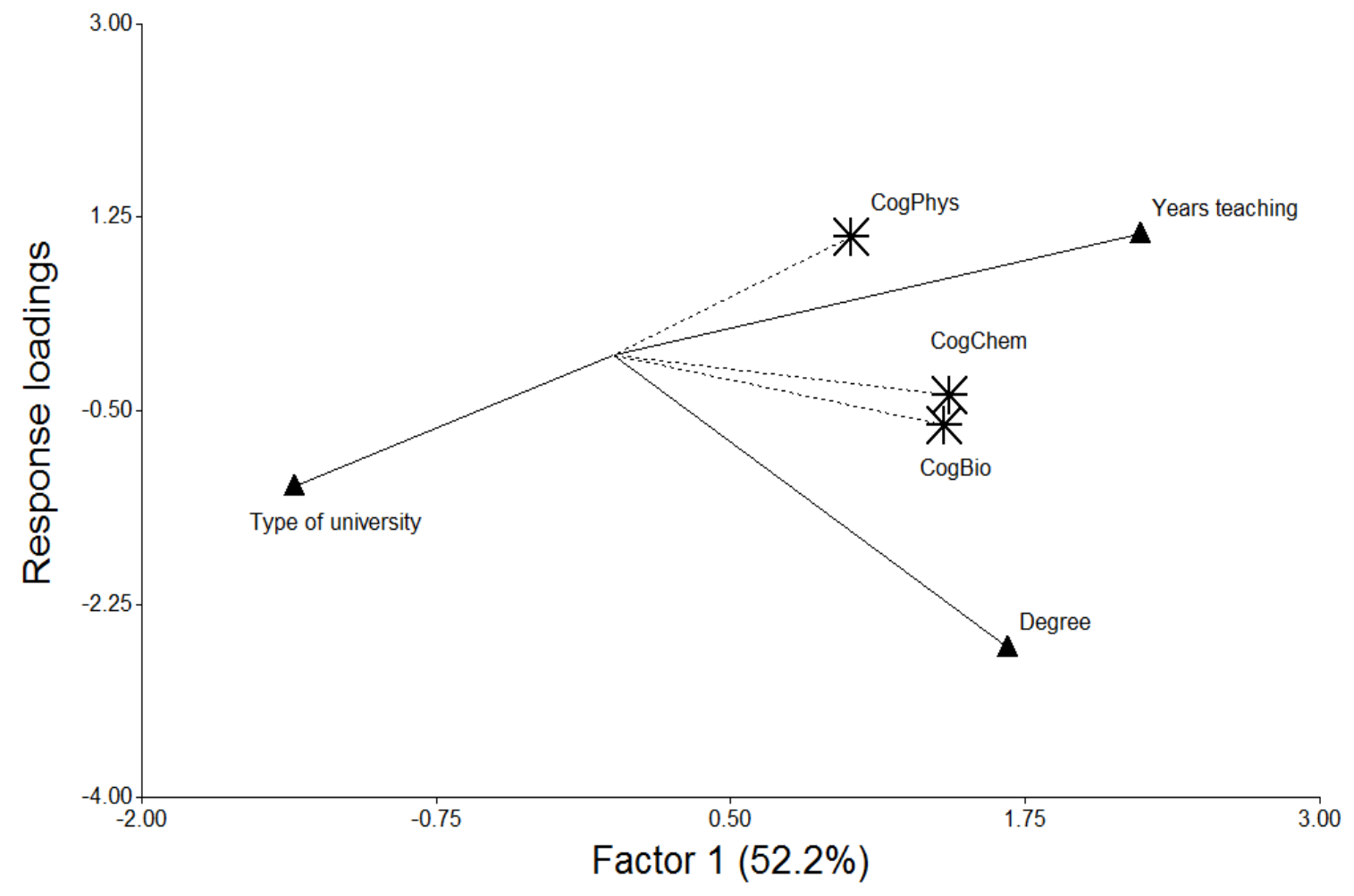

Figure 2. Biplot showing the correlation between cognitive (Cog) tests in chemistry (Chem), physics (Phys) and biology (Bio), and academic degree (higher degrees are represented by higher values of Factor 1), years of teaching experience, and type of university (higher values represent private universities, and lower values public ones). Results are based on the Partial Least Squares analysis.

We found that years of teaching was a poor predictor of most affective results except A1 in biology and A2 in chemistry, and to a lesser extent A2 in biology, as there seems to be a weak negative correlation (Figure 3); thus, fewer years of teaching are correlated with more positive assessments of biology, and also with greater difficulties in understanding these subjects. The degree earned was negatively correlated with A2 in physics, and positively correlated with A1 in all sciences. Therefore, teachers with higher academic degrees also appear to like all topics more 
than teachers with lower degrees, and a higher degree also decreases the level of perceived difficulty in physics. Finally, the type of university (i.e., private or public) is positively correlated with the affective domain A2, primarily in physics but also in biology and chemistry, and negatively correlated with A1 (Figure 3). These results indicate that teachers that graduated from private universities perceive a greater difficulty with, and greater dislike for, all three sciences.

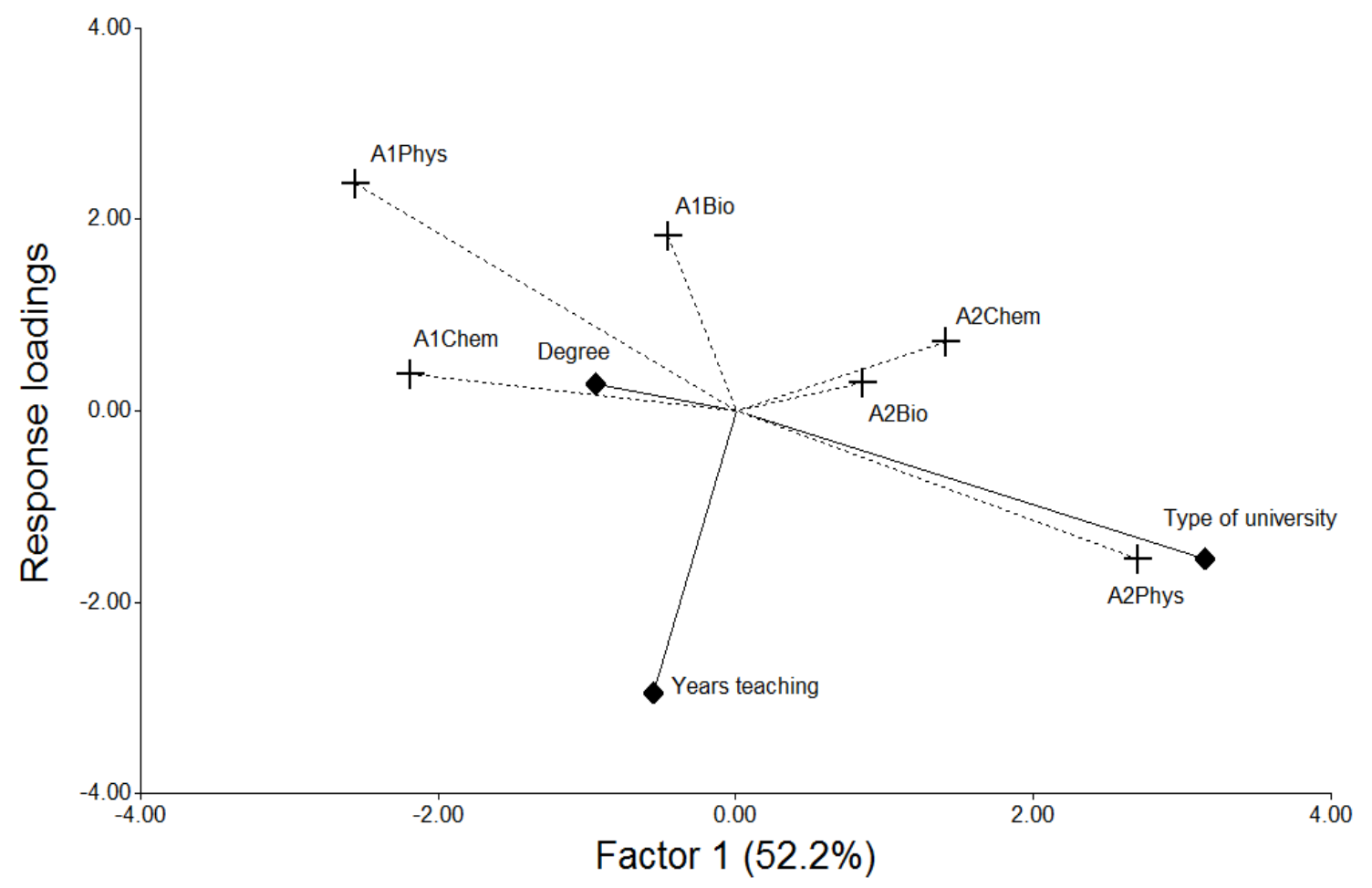

Figure 3. Biplot showing the correlation between affective results A1 and A2 in chemistry (Chem), physics (Phys) and biology (Bio), and academic degree (higher degrees are represented by higher values of Factor 1), years of teaching, and type of university (higher values represent private universities, and lower values public ones). Results are based on the Partial Least Squares analysis.

\section{Discussion:}

To assess if teacher's attitude towards science serves as predictor for cognitive competence we tested a cohort of rural teachers in both both affective and cognitive proficiency in and about each discipline. The data collected and analysed suggest that there is a clear correlation between the cognitive and affective domains. Cognitive knowledge (mastery) of the subject matter is associated with a more positive disposition, or enjoyment, (A1) towards the subject, whether it is biology, chemistry, or physics. On the other hand, mastery is associated 
differently with a perception of difficulty for the three disciplines. Mastery is associated with greater difficulty (A2) in biology, lower perception of difficulty in chemistry and no association in the case of physics. These findings provide empirical evidence that both enjoyment and perception of difficulty can serve as predictor for cognitive mastery. This is important because career choices in science education may be better mediated when these two aspects of the affective domain are taken into account. It is difficult to learn that which is not appealing as it undermines self-efficacy (Betz \& Hackett, 1986; Chesnut \& Burley, 2015; Yada, Tolvanen, \& Savolainen, 2017).

Mastery of the subject matter was also associated with other variables, including years of service, type of university, and academic degree; these variables may also explain the association of mastery with A1 and A2. For example, years of service is associated with better mastery of the subject in physics and less in biology and chemistry, whereas a higher academic degree is associated with better proficiency in biology and chemistry but not in physics. It is worth remembering these data are cross-sectional. This evidence may show general changes in preservice training over the years with teachers who graduated a longer time ago having better training in physics than more recent graduates. As underscored below, teachers whose degree came from a public university performed better in the content tests. Since private university programs are newer than those from public universities, one could presume teachers with more years of service represent public institutions to a higher extent. Thus, consistency of trends for years of service and type of university is mutually validating. Another reading of this observation in that while knowledge in biology and chemistry is solidified through formal learning, in the case of physics years of service is more relevant for mastery of the subject matter. Thus, for this cohort of teachers physics would be learned more through teaching (preparing and reviewing) than by earning additional academic degrees. This speaks of the different natures of the three sciences and of the particularities associated with learning and teaching each subject, for instance the level of abstraction necessary to master each of them (Bucat, 2004; Sandi-Urena, 2018). In addition, data indicated that private university training is associated with less mastery of the subject, especially in physics. This is consistent with other findings regarding private higher education in Costa Rica (Levy, 2015). Lowering graduate rates for secondary school students from 1996 through 2007 are related to the number of teachers with degrees from private 
universities (Jiménez Romero, 2009). It is, thus, important to review the apparent training gap between private and public teachers' programs (Haba, 2002). Using an attitude/knowledge predictor scheme for incoming students in private universities might narrow that gap. This is especially important because private universities provide the highest percentage of teachers to the public educational system with about 65 percent, and continues to increase (Jiménez Romero, 2009; Levy, 2015). Thus, closing such gaps deems to be necessary. Especially in the area where data for this study were gathered since there are no public institutions offering degrees in Science Education and relocating to places where such programs are available is onerous in excess.

In addition, we also found that training in a private university is associated with both a perception of greater difficulty and a lesser disposition towards the three subjects, biology, chemistry and physics. That is, teachers holding degrees from private universities in Costa Rica have a lesser liking for the three sciences and find them more difficult than those who graduated from public universities. A better disposition towards the three subjects is also associated with higher academic degrees. Holding higher degrees may contribute to teachers' self-efficacy beliefs, that is, judgements of their capabilities to successfully attain a goal (Bandura, 1986). In turn, higher self-efficacy beliefs are associated with higher motivation, persistence and improved performance (Jungert \& Rosander, 2010; Zimmerman \& Lebeau, 2000). These observations stress the significance of sound pre-service training, especially for cohorts that may be relatively isolated and with little access to professional development opportunities. Years of service do not make up for initial university training (except for physics). Achieving competence in a subject is harder to attain when the perception of difficulty is greater because it undermines self-efficacy (Betz \& Hackett, 1986; Yada, Tolvanen, \& Savolainen, 2017). Therefore, in light of the difference between public and private education, it would be advisable that public universities increase their presence and training of science teachers in the region.

We observed that the perception of difficulty for physics is less dependent on years of service. Contrary to that, biology and chemistry were perceived more difficult by teachers with more years of service than those less experienced. As above, this suggests changes in the overall perception of the sciences as teaching programs evolve in institutions, especially with the continuous emerging of newer programs in private universities.

In conclusion, the affective domain has a direct relationship with the cognitive domain. 
The results of this study provide strong support for the stance that the attitude towards science impacts teacher's abilities to master the discipline. The affective domain, therefore, could serve as a predictor for cognitive competency and self-efficacy expectancies with respect to both content and career fulfilment. This is important because the affective domain can be used as an input in career selection processes. By improving career and selection processes teachers could be more satisfied with their choices and experience greater sense of accomplishment, and science education could improve. The ideal is to have teachers with better affective and cognitive competencies, thus capable of better mediating student learning (Grauer, 2014). Teachers and students with higher affective and cognitive competencies in sciences can better drive the engine of change in regions that lag behind in social, economic and overall development. (Hanushek, Jamison, Jamison, \& Woessman, 2008; Hanushek \& Woessmann, 2012). We expect that future research with larger teacher populations could serve to confirm and corroborate our results.

\section{References:}

Anderson, L. W. (2005). Objectives, evaluation, and the improvement of education. Studies in Education Evaluation, 31, 102-113.

Anderson, L. W., Krathwohl, D. R., Airasian, P., Cruikshank, K., Mayer, R., Pintrich, P., Wittrock, M. (2001). A taxonomy for learning, teaching and assessing: A revision of Bloom's taxonomy. In Artz, AF, \& Armour-Thomas, E.(1992). Development of a cognitivemetacognitive framework for protocol analysis of mathematical problem solving in small groups. Cognition and Instruction (Vol. 9, pp. 137-175). New York: Longman Publishing.

Baker, C. (2010). The impact of instructor immediacy and presence for online student affective learning, cognition, and motivation. Journal of Educators Online, 7(1), 1-30. Retrieved from http://eric.ed.gov/?q=EJ904072\&id=EJ904072

Bandura, A. (1986). Social foundations of thought and action. Englewood Cliffs, NJ, 1986.

Bathgate, M., \& Schunn, C. (2017). Factors that deepen or attenuate decline of science utility value during the middle school years. Contemporary Educational Psychology. http://doi.org/10.1016/j.cedpsych.2017.02.005

Betz, N. E., \& Hackett, G. (1986). Applications of Self-Efficacy Theory to Understanding Career Choice Behavior. Journal of Social and Clinical Psychology, 4(3), 279-289. 
http://doi.org/10.1521/jscp.1986.4.3.279

Bucat, R. (2004). Pedagogical Content Knowledge As a Way Forward: Applied Research in Chemistry Education. Chem. Educ. Res. Pract., 5(3), 215-228. http://doi.org/10.1039/B4RP90025A

Chesnut, S. R., \& Burley, H. (2015). Self-efficacy as a predictor of commitment to the teaching profession: A meta-analysis. Educational Research Review, 15, 1-16. http://doi.org/10.1016/j.edurev.2015.02.001

Díaz, S., Umaña, R., Quesada, H., Benavides, L., \& Sandí, R. (2012). Biología, Programas de Estudio (Vol. 2012). San José: MEP. Retrieved from http://www.dgb.sep.gob.mx/02-m1/03iacademica/programasdeestudio.php

Di Rienzo, J. A., Casanoves, F., Balzarini, M. G., Tablada, M., \& Robledo, C. W. (2017). InfoStat. Córdoba: InfoStat Group, Universidad Nacional de Córdoba.

Dreyfuss, S. E., \& Dreyfus, H. L. (1980). A five-stage model of the mental activities involved in directed skill acquisition. Operations Research Center, (February), 1-18. http://doi.org/ADA084551

Grauer, B. (2014). Secondary Science Teachers' Use of the Affective Domain in Science Education. Kansas State University.

Haba, E. P. (2002). El Desafío (Contraacadémico) de las Universidades Privadas en Costa Rica. Revista de Ciencias Sociales, III(97), 79-93.

Hanushek, E. a., \& Woessmann, L. (2012). Do better schools lead to more growth? Cognitive skills, economic outcomes, and causation. Journal of Economic Growth, 17(4), 267-321. http://doi.org/10.1007/s10887-012-9081-x

Hanushek, E., Jamison, D. T., Jamison, E. A., \& Woessman, L. (2008). Education and Economic Growth. It's not just going to school, but learning something while there that matters. Education Next, 8(2), 62-71.

Jiménez Romero, A. (2009). Análisis del rendimiento de la educación regular, desde el punto de vista de la formación docente universitaria. Revista Digital Matemática, 9(2), 1-15.

Jungert, T., \& Rosander, M. (2010). Self-efficacy and strategies to influence the study environment. Teaching in Higher Education, 15(6), 647-659.

http://doi.org/10.1080/13562517.2010.522080

Knuver, A. W. M., \& Brandsma, H. P. (1993). Cognitive and Affective Outcomes in School 
Effectiveness Research. School Effectiveness and School Improvement, 4(3), 189-204. http://doi.org/10.1080/0924345930040302

Krathwohl, D. R., \& Anderson, L. W. (2010). Merlin C. Wittrock and the revision of bloom's taxonomy. Educational Psychologist, 45(1), 64-65. http://doi.org/10.1080/00461520903433562

Kraus, S. J. (1995). Attitudes and the Prediction of Behavior: Meta-Analysis of the emperical literature. Personality and Social Psuchology Bulletin, 21(1), 58-75.

Levy, D. C. (2015). Costa Rica: Public Continuity, Private Gains. International Higher Education, 43, 22-23.

Sandi-Urena, S. (2018). Phenomenological Approaches to Study Learning in the Tertiary Level Chemistry Laboratory. Química Nova, 41(2), 236-242.

Sellin, N. (1995). Partial least squares modeling in research on educational achievement. In W. Bos \& R. H. Lehmann (Eds.), Reflections on Educational Achievement (pp. 256-267). Hamburg: Waxmann.

Sevilla Solano, C., Calderón Solano, C., Hernández Jiménez, C., \& Villalobos Salas, J. (2012). Programas de Estudio CIENCIAS: Tercer Ciclo de Educación Básica. San José: Ministerio de Educación Pública.

Shoffner, M. (2009). The place of the personal: Exploring the affective domain through reflection in teacher preparation. Teaching and Teacher Education, 25(6), 783-789. http://doi.org/10.1016/j.tate.2008.11.012

Thompson, T. L., \& Mintzes, J. J. (2002). Cognitive structure and the affective domain: On knowing and feeling in biology. International Journal of Science Education, 24(6), 645660. http://doi.org/10.1080/09500690110110115

Valverde, M., Alfaro, G., Navas, M., Castillo, X. M., \& Acón, I. (2012). Química, Programa de Estudio. San José: MEP.

Villalobos, J. M., \& Jiménez, R. I. (2012). Física, Programa de Estudios. Programa de Estudios. San José: MEP.

Walls, R. T., Nardi, A. H., von Minden, A. M., \& Hoffman, N. (2002). The Characteristics of Effective and Ineffective Teachers. Teacher Education Quarterly, 29(1), 39-48. Retrieved from http://www.jstor.org/stable/jthought.49.1-2.27

Yada, A., Tolvanen, A., \& Savolainen, H. (2017). Teachers' attitudes and self-efficacy on 
implementing inclusive education in Japan and Finland: A comparative study using multigroup structural equation modelling. Teaching and Teacher Education, 75, Manuscript submitted for publication. http://doi.org/10.1016/j.tate.2018.07.011

Zimmerman, B. J., \& Lebeau, R. B. (2000). A commentary on self-directed learning. In C. E. Evensen, D. H. and Hmelo-Silver (Ed.), Problem-based learning: A research perspective on $l$

$e$

a

$r$

$n$

$i$

$n$

$g$

$i$

n

$t$

$e$

$r$

$a$

$c$

$t$

$i$

o

$n$

S 